\section{Dampak Literasi Dan Inkuisi Keuangan Terhadap Kinerja Pelaku UMKM Di Kota Bogor}

\author{
Ratih Puspitasari dan Danti Astrini \\ Institut Bisnis dan Informatika Kesatuan Bogor \\ Email :
}

\section{PENDAHULUAN}

Usaha Mikro, Kecil dan Menengah (UMKM) adalah salah satu bentuk bisnis yang bergerak dalam berbagai bidang usaha pemberdayaan masyarakat, tidak hanya di Indonesia tetapi juga di negara-negara Asia Tenggara. Presiden Joko Widodo ketika berbicara dalam ASEAN Leaders Interface with ASEAN Business Advisory Council (ABAC) di Philippine International Convention Center (PICC), menyampaikan bahwa "Pelaku UMKM merupakan tulang punggung perekonomian bagi negara-negara Asia Tenggara yang tergabung dalam ASEAN". (Media Indonesia, 2017). Jose Antonio Morato Tavares Direktur Jenderal Kerjasama Ekonomi ASEAN Kementrian Luar Negeri juga mengungkapkan bahwa "UMKM dapat menjadi tulang punggung perekonomian ASEAN dan juga Indonesia. Ia menjelaskan bahwa UMKM memberikan kontribusi hingga 59 persen pada ASEAN". (CNN Indonesia 2017). Rohmad Hadiwijoyo, Ketua Dewan Direktur CIDES (Center for Information and Development Studies) menyatakan bahwa "Ada tiga faktor yang membuat usaha mikro, kecil dan menengah (UMKM) bisa bertahan dalam kondisi ekonomi yang krisis, yaitu:

1. Umumnya UMKM menghasilkan barang konsumsi dan jasa yang dekat dengan kebutuhan masyarakat

2. Pelaku usaha UMKM umumnya memanfaatkan sumber daya lokal, baik itu untuk sumber daya manusia, modal, bahan baku, hingga peralatan.

3. Umumnya bisnis UMKM tidak ditopang dana pinjaman dari bank, melainkan dari dana sendiri." (Kompas, 2012).

Data dari Badan Pusat Statistik (BPS) mencatat bahwa jumlah UMKM setelah pasca krisis ekonomi tidak berkurang. Tabel 1 menunjukan bahwa jumlah UMKM dari tahun 2010 sampai dengan tahun 2018 mengalami peningkatan, bahkan Bhima Yudhistira, ekonom Indef memperkirakan bahwa "Pada tahun 2017-2020 jumlah UMKM akan mencapai 65 juta unit, baik itu unit usaha mikro, kecil dan menengah, meskipun ada tantangan yang cukup besar khususnya bagi sektor industri pengolahan." (Republika.co.id). Menurut Ashariyadi Sekretaris Direktorat Jenderal kerja sama ASEAN Kementrian Luar Negeri RI, "Kemampuan bertahannya UMKM terhadap krisis tersebut disebabkan fleksibilitas UMKM dalam melakukan penyesuaian proses produksinya, mampu berkembang dengan modal sendiri, tidak bergantung pada hutang luar negeri." (Masyarakat ASEAN, 2016).

Tabel 1. Perkembangan Jumlah UMKM (2010 - 2019)

$\begin{array}{ccc}\text { Tahun } & \text { Jumlah UMKM (Unit) } & \text { Pertumbuhan Jumlah UMKM (\%) } \\ 2010 & 52.764 .750 & \\ 2011 & 54.114 .821 & 2,55 \\ 2012 & 55.206 .444 & 2,01 \\ 2013 & 56.534 .592 & 2,40 \\ 2014 & 57.895 .721 & 2,40 \\ 2015 & 59.262 .772 & 2,36 \\ 2016 & 61.656 .547 & 4,03 \\ 2017 & 62.928 .077 & 2,06 \\ 2018 & 64.194 .057 & 2,02\end{array}$

(Sumber: Kementerian Koperasi dan Usaha Kecil dan Menengah (data diolah))
Financial Literacy and Inclusion in MSME

Performance

Submitted: MARET 2021

Accepted: JUNI 2021

\section{JIMKES}

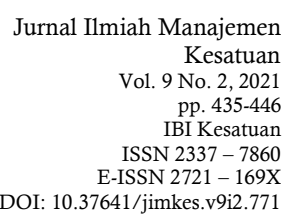


Financial Literacy and Inclusion in MSME Performance
Berdasarkan data dari Kementerian Koperasi dan Usaha Kecil dan Usaha Menengah pada Gambar 1 menunjukan jumlah unit usaha di Indonesia sejak tahun 2010 sampai dengan 2018 mengalami peningkatan. Perkembangan unit usaha sampai dengan tahun 2018 mencapai jumlah 64.199.606 terdiri dari UMKM sebanyak 64.194.057 unit dan Usaha besar sebanyak 5.550 unit atau hanya sebesar 8,64 persen dibandingkan dengan UMKM.

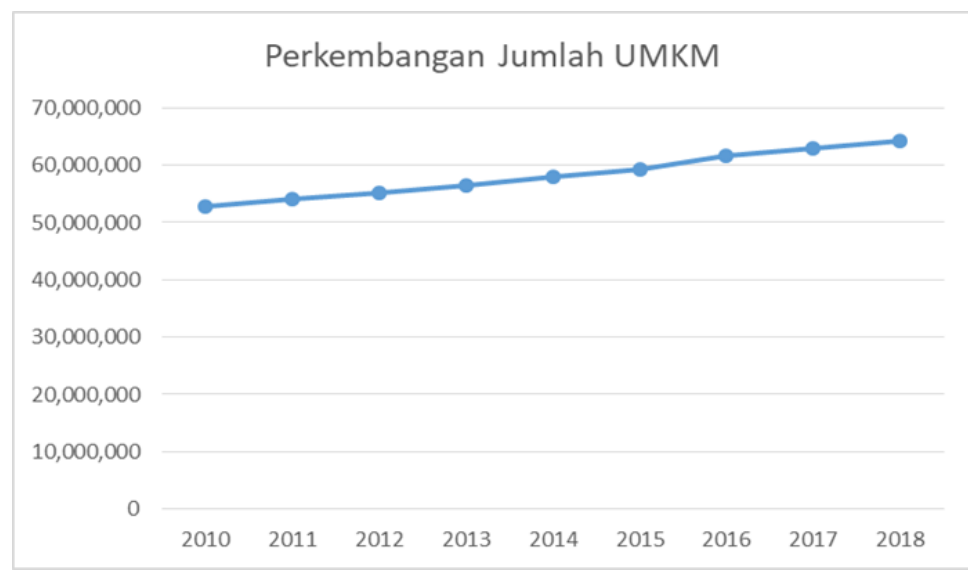

Gambar 1. Grafik Perkembangan Jumlah UMKM Tahun 2010 - 2018

(Sumber: Kemetrian Koperasi dan UKM (data diolah))

\section{Kontribusi UMKM dengan Usaha Besar Terhadap PDB}

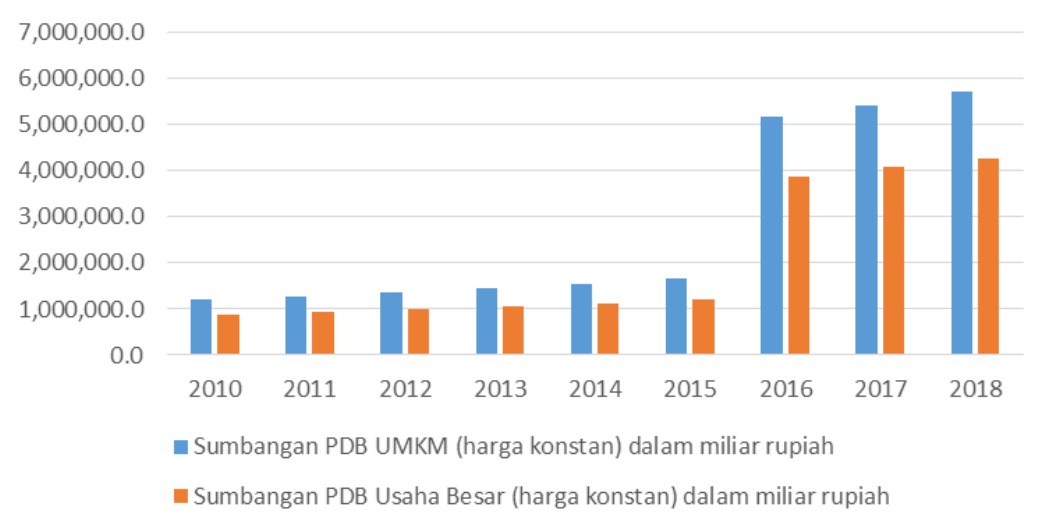

\section{Gambar 2.Grafik Perbandingan Kontribusi UMKM dengan Usaha Besar Terhadap PDB}

(Sumber: Kementrian Koperasi dan UKM (data diolah))

Grafik di atas menggambarkan sumbangan UMKM terhadap PDB atas Harga Konstan sepanjang tahun 2010 sampai dengan tahun 2018. Kontribusi UMKM dan Usaha Besar terhadap PDB Nasional menurut harga konstan ke duanya memiliki trend yang meningkat secara signifikan, namun kontribusi UMKM terhadap PDB secara umum memiliki trend meningkat yang lebih besar dibandingkan dengan kontribusi Usaha Besar terhadap PDB. 


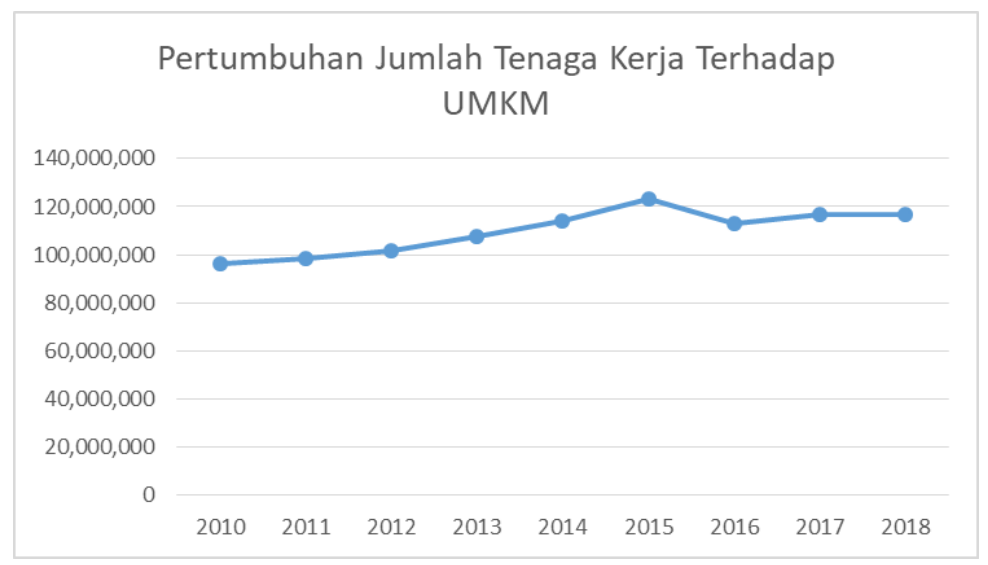

Financial Literacy and Inclusion in MSME

Performance

\section{Gambar 3. Grafik Pertumbuhan Jumlah Tenaga Kerja Terhadap UMKM}

Sumber: Kementrian Koperasi dan Usaha Kecil dan Usaha Menengah (data diolah)

Perkembangan kontribusi tenaga kerja terhadap UMKM seperti yang digambarkan pada Gambar 3. memiliki kontribusi yang meningkat meskipun di tahun 2015 ke 2016 mengalami penurunan sebesar 1,83 persen tetapi pada tahun 2016 kembali meningkat sebesar 3,90 persen.

Kementrian Koperasi dan Usaha Kecil Menengah (UKM) juga mencatat bahwa, "Dalam lima tahun terakhir sejak tahun 2010, serapan tenaga kerja pada sektor UMKM tumbuh dari 96,99 persen menjadi 97,22 persen." (CNN Indonesia, 2016). Pertumbuhan produksi industri manufaktur mikro dan kecil berdasarkan data dari BPS per Agustus 2017 pada kuartal I sebesar 6,63 persen, lebih rendah di bandingkan pertumbuhan pada periode yang sama sebesar 6,56 persen di tahun 2016. Capaian pertumbuhan pada kuartal II di tahun 2017 mengalami penurunan, dengan pertumbuhan hanya sebesar 2.5 persen, penurunan tersebut mencerminkan pertumbuhan UMKM dalam kondisi yang kurang baik sebagai akibat dari lesunya sektor perdagangan dan industri di tahun 2017. Menurut Bima Yudhistira, Ekonom Indef bahwa "Kalo UMKM-nya pertumbuhannya kurang bagus, pertumbuhan ekonominya sulit mencapai target 5,2 persen, apalagi di 2018 targetnya 5,4 persen." (Republika.co.id, 2017).

Menteri Koperasi (Menkop) dan UKM, Anak Agung Gede Ngurah Puspayoga juga menyampaikan, berdasarkan data yang diperoleh dari data online system (DOS) Kemenkop dan UMKM (Grafik 1.4), jumlah UMKM per Desember 2017 adalah sebanyak 59.697.827 unit, terdiri dari usaha mikro sebesar 58,9 juta, usaha kecil 716,8 ribu, usaha menengah 65,5 ribu unit, dan usaha besar 5,03 ribu unit. (LEGALERA.ID, 2018). Perkembangan jumlah UMKM ini, tentunya mengharuskan para pelaku UMKM siap menghadapi persaingan, sehingga diharapkan UMKM memiliki kinerja yang baik. Kinerja UMKM merupakan ukuran yang dapat memberikan gambaran sejauhmana UMKM tersebut dapat mencapai tujuan yang telah ditetapkan, oleh karena itu pelaku UMKM diantaranya harus memiliki kemampuan dan pengetahuan tentang keuangan (literasi keuangan) agar dapat mengelola keuangan secara efektif.

Salah satu faktor yang dapat meningkatkan literasi keuangan adalah inklusi keuangan yang berguna dalam meningkatkan akses keuangan bagi pelaku UMKM. Hasil survey OJK pada tahu 2017 mengenai literasi keuangan Nasional menunjukkan bahwa indeks inklusi keuangan masyarakat Indonesia mengalami peningkatan dari 59,7 persen pada tahun 2013 menjadi 67,8 persen di tahun 2016. Namun demikian Menurut Deputi Komisioner Otoritas Jasa Keuangan Sukarela Batunaggar mengatakan bahwa inklusi keuangan masih tergolong rendah hanya 60 persen penduduk dewasa yang memiliki rekening bank, terlebih lagi jumlah penduduk Indonesia yang cukup banyak (Hikam, 2019). Strategi Nasional Keuangan Inklusif tertuang dalam Peraturan Presiden Nomor 82 tahun 2016 yang menargetkan pencapaian indeks inklusi keuangan sebesar 75 persen pada tahun 2019. Inklusi keuangan menjadi perhatian pemerintah sebab memiliki peran 
Financial Literacy and Inclusion in MSME Performance

\section{8}

dalam mendorong pertumbuhan ekonomi Nasional yang berkelanjutan, mengurangi kesenjangan serta dapat meningkatkan kesejahteraan masyarakat.

Berdasarkan pemaparan tersebut di atas maka penelitian ini akan mengkaji lebih lanjut mengenai literasi dan inkuisi keuangan pelaku UMKM di kota Bogor serta bagaimana pengaruhnya terhadap kinerja UMKM, dengan cara menggunakan indikator yang sudah banyak digunakan oleh penelitian terdahulu.

Berdasarkan latar belakang penelitian tersebut, tujuan penelitian ini adalah untuk mengkaji lebih lanjut. (1) Bagaimana pengaruh literasi keuangan terhadap kinerja pelaku UMKM di kota Bogor? (2) Bagaimana pengaruh inklusi keuangan terhadap kinerja pelaku UMKM di kota Bogor? (3) Bagaimana pengaruh literasi keuangan dan inklusi keuangan terhadap kinerja pelaku UMKM di kota Bogor?

\section{Kerangka Pemikiran}

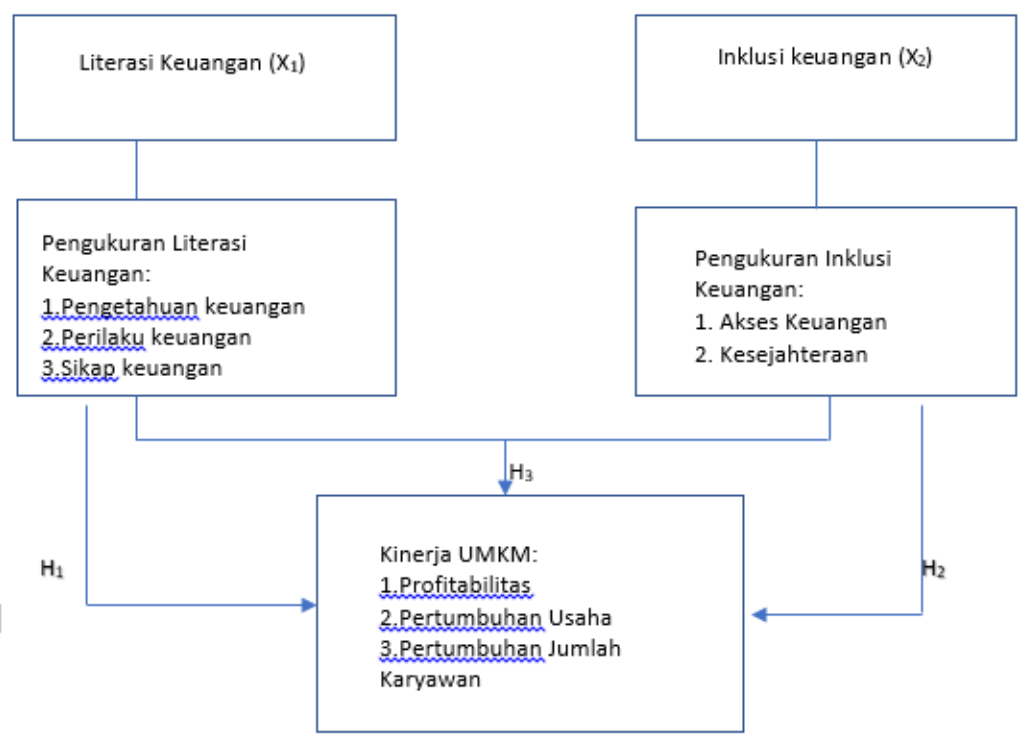

Gambar 4. Kerangka Konseptual

\section{Hipotesis}

Berdasarkan kerangka konseptual tersebut, maka hipotesis yang diajukan dalam penelitian ini adalah sebagai berikut:

1. Literasi keuangan berpengaruh terhadap kinerja UMKM

2. Inklusi keuangan berpengaruh terhadap kinerja UMKM

3. Literasi keuangan dan inklusi keuangan berpengaruh terhadap kinerja UMKM

\section{METODE PENELITIAN}

Metode penelitian yang digunakan dalam penelitian ini adalah metode survey dengan menggunakan kuesioner. Penelitian ini dibatasi hanya pelaku UMKM di kota Bogor yang dilakukan pada bulan November 2021.

Data yang digunakan di dalam penelitian ini merupakan data hasil survei terhadap 102 responden. Pada data tidak terdapat data yang hilang (missing data). Sebelum analisis regresi dilakukan, nilai-nilai hasil jawaban responden yang berupa nilai likert digabungkan terlebih dahulu dengan menggunakan analisis faktor (dengan bantuan program SmartPLS 2.0), sehingga pada akhirnya akan terdapat tiga variabel saja, yaitu variabel Literasi Keuangan (X1), Inklusi Keuangan (X2), dan Kinerja UMKM (Y). Seluruh proses analisis regresi dilakukan dengan menggunakan software SPSS versi 20. 


\section{Operational Variabel Penelitian}

Operasional variabel menjabarkan konsep dimensi dan indikator yang digunakan dalam variabel penelitian ini. Adapun penelitian ini meliputi tiga variabel yaitu literasi keuangan (X1), inklusi keuangan (X2) dan kinerja UMKM (Y).

\section{Uji Kualitas Data}

Uji Validitas. Pengujian validitas pada penelitian ini dilakukan untuk menguji jika variabel indikator telah mampu mengukur variabel laten yang memang ingin diukur dengan baik. Nilai yang digunakan dalam pengujian ini adalah nilai Average Variance Extracted (AVE). Nilai AVE berkisar antara 0 sampai 1, dengan nilai yang mendekati angka 1 menunjukkan tingkat validitas yang semakin tinggi. Berdasarkan literatur nilai AVE yang baik adalah apabila lebih besar dari 0.5 (>0.5) (Sekaran \& Bougie, 2017).

Uji Reliabilitas. Pengujian reliabilitas pada penelitian ini dilakukan untuk menguji tingkat reliabilitas variabel indikator. Tingkat reliabilitas merupakan suatu ukuran kekonsistenan pertanyaan kuesioner / indikator dalam mengukur nilai variabel laten. Kekonsisten yang dimaksud di sini adalah apabila pertanyaan kuesioner ditanyakan kepada responden yang sama secara berulang-ulang kali akan menghasilkan jawaban yang sama. Nilai yang digunakan dalam pengujian reliabilitas adalah nilai Cronbach's Alpha (CA). Nilai CA berkisar antara 0 sampai 1, dengan nilai yang mendekati angka 1 menandakan bahwa tingkat reliabilitasnya semakin baik. Berdasarkan literatur nilai CA yang baik adalah jika nilainya lebih besar dari 0.7 (> 0.7) (Sekaran \& Bougie, 2017).

\section{Uji Asumsi Klasik}

Uji Asumsi Regresi (Normalitas). Pengujian asumsi normalitas dibutuhkan di dalam analisis regresi pada penelitian ini dikarenakan pengujian signifikansi nilai koefisien regresi menggunakan uji-t yang berbasis dari sebaran data normal. Apabila asumsi normalitas ini tidak dipenuhi, maka validitas hasil pengujian nilai koefisien regresi juga akan menjadi tidak baik.

Pengujian asumsi normalitas dilakukan dengan beberapa cara, namun dalam penelitin ini cara yang termudah dan sederhana adalah dengan menggunakan Q-Q Plot (QuantileQuantile Plot).

Uji Asumsi Regresi (Multikolinieritas). Uji multikolinieritas dalam penelitian ini bertujuan untuk menemukan apakah dalam model regresi ditemukan adanya korelasi antar variabel independen (bebas).

Uji Asumsi Regresi (Homoscedasticity). Uji Homoscedasticity pada penelitian ini dilakukan untuk memastikan bahwa variabel di dalam regresi memiliki keragaman yang sama. Apabila asumsi ini tidak terpenuhi maka kesimpulan dari uji-t (pengujian nilai koefisien regresi) akan menjadi bias. Pengujian Homoscedasticity dilakukan dengan membuat plot residual, yaitu plot antara nilai residual/error analisis regresi dengan nilai prediksi analisis regresi. Hasil analisis regresi dikatakan telah memenuhi asumsi ini apabila pola titik-titik pada plot residual tidak membentuk pola tertentu, yaitu tersebar secara acak (Ghozali, 2011).

Uji Asumsi Regresi (Linearitas). Pengujian asumsi Linearitas pada analisis regresi dalam penelitian ini dibutuhkan karena asumsi dari model regresi adalah hubungan antara variabel dependen dengan independen adalah linear (tidak ada variabel independen yang dikuadratkan atau memiliki bentuk akar sebagai contoh). Pengujian Linearitas secara otomatis akan terpenuhi apabila asumsi normalitas dan asumsi Homoscedasticity telah terpenuhi.

\section{HASIL DAN PEMBAHASAN}

Ekspolorasi data primer yang diambil secara online dengan menggunakan kuesioner terhadap pelaku UMKM di Kota Bogor. Sampel pada penelitian ini berjumlah 102 responden pelaku UMKN yang terdapat di wilayah Kota Bogor.
Financial Literacy and Inclusion in MSME

Performance 
Financial Literacy and Inclusion in MSME Performance

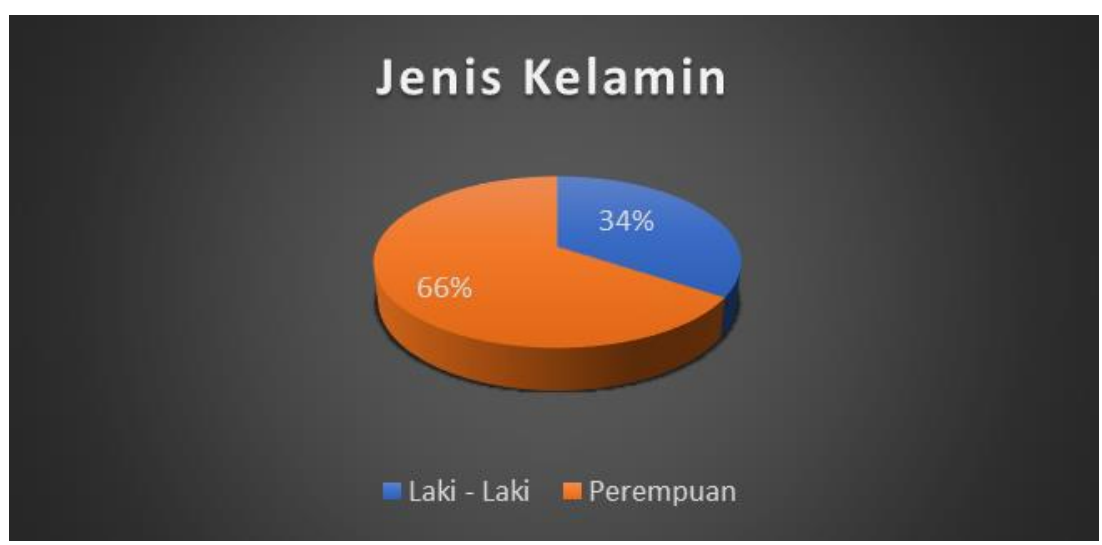

\section{Gambar 5. Persentase Jenis Kelamin Sample UMKM Kota Bogor}

Gambar 5, menunjukkan bahwa sebanyak 65.7 persen responden berjenis kelamin perempuan dan 34.3 persen responden berjenis kelamin laki - laki. Adapun rincian jumlah dapat di lihat pada Tabel 1 dibawah ini. Hal ini mencerminkan bahwa pelaku UMKM di kota Bogor didominasi oleh perempuan yaitu sebesar 67 responden.

Tabel 2. Jenis Kelamin Responden

\begin{tabular}{|c|c|c|}
\hline Jenis Kelamin & Frekuensi & Persentase \\
\hline Laki-laki & 35 & 34.3 \\
Perempuan & 67 & 65.7 \\
\hline Total & $\mathbf{1 0 2}$ & $\mathbf{1 0 0 . 0}$ \\
\hline
\end{tabular}

Berdasarkan hasil pengumpulan data yang dilakukan dengan menggunakan google form diperoleh hasil jumlah rekapitulasi rentang usia responden pelaku UMKM di Kota Bogor dijelaskan pada Gambar 6 dan Tabel 3 berikut di bawah ini.

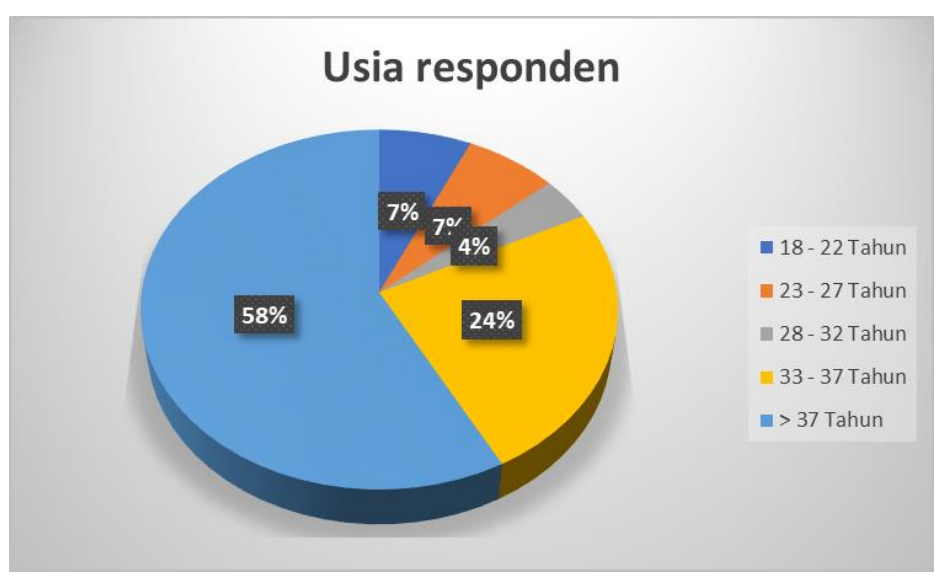

Gambar 6. Persentase Usia Responden UMKM Kota Bogor

Berdasarkan rekapitulasi data primer diperoleh hasil usia responden UMKM paling banyak berusia diatas 37 tahun dengan persentase 57.8 persen, selanjutnya dilanjutkan dengan rentang usia 33 - 37 tahun dengan persentase 24.5 persen dari total responden sebanyak 102. Tabel 3 menunjukkan bahwa mayoritas responden memiliki usia diatas 37 tahun dengan jumlah 59 responden. 
Tabel 3. Usia Responden

\begin{tabular}{|l|r|r|}
\hline Usia & Frekuensi & Persentase \\
\hline 18 - 22 Tahun & 7 & 6.9 \\
23 - 27 Tahun & 7 & 6.9 \\
28 - 32 Tahun & 4 & 3.9 \\
33 - 37 Tahun & 25 & 24.5 \\
$>$ 37 Tahun & 59 & 57.8 \\
\hline Total & $\mathbf{1 0 2}$ & $\mathbf{1 0 0 . 0}$ \\
\hline
\end{tabular}

Berdasarkan hasil pengumpulan data, pada Tabel 4 dibawah ini menunjukkan bahwa sebesar 70.6 persen responden memiliki latar belakang pendidikan setara SMA/SMK, sedangkan untuk responden yang memiliki latar belakang pendidikan setara dengan sarjana sebesar 10.8 persen atau berjumlah 11 responden. Selanjutnya untuk tingkat diploma sebesar 7.8 persen, tingkat SMP sebesar 9.8 persen, dan hanya 1 persen untuk tingkat S2/S3.

Tabel 4. Persentase Pendidikan Terakhir sample UMKM Kota Bogor

\begin{tabular}{|l|r|r|}
\hline Pendidikan Terakhir & Frekuensi & Persentase \\
\hline SMP & 10 & 9.8 \\
SMA/SMK & 72 & 70.6 \\
Diploma & 8 & 7.8 \\
Sarjana & 11 & 10.8 \\
S2/S3 & 1 & 1.0 \\
\hline Total & $\mathbf{1 0 2}$ & $\mathbf{1 0 0 . 0}$ \\
\hline
\end{tabular}

Responden dalam penelitian ini memiliki berbagai jenis usaha yang beraneka ragam. Pada Tabel 5 di bawan ini menunjukkan bahwa 49 responden memiliki jenis usaha kategori lain-lain yang didalamnya sebagian besar adalah usaha di bidang pangan. Sedangkan sebanyak 36 dari responden memiliki usaha retail /eceran.

Tabel 5. Jenis Usaha

\begin{tabular}{|l|r|r|}
\hline Pilihan Jenis Usaha & \multicolumn{1}{|c|}{ Frekuensi } & Persentase \\
\hline Manufacturing/mesin & 1 & 1.0 \\
Wholesale/Agen & 7 & 6.9 \\
Service/Jasa & 9 & 8.8 \\
Retail/eceran & 36 & 35.3 \\
Lain-lain & 49 & 48.0 \\
\hline Total & $\mathbf{1 0 2}$ & $\mathbf{1 0 0 . 0}$ \\
\hline
\end{tabular}

Omset perbulan responden UMKM Kota Bogor dibagi kedalam 2 kelompok angka. Pada Tabel 6 di bawah ini menunjukkan bahwa mayoritas responden atau sebesar 81.4 persen memiliki omset kurang dari 25 juta per bulan, sedangkan sebanyak 18.6 persen dari responden memiliki omset dengan kisaran angka 25.000.001 hingga 208.000.000 perbulan.

Tabel 6. Omset Perbulan Responden

\begin{tabular}{|c|c|c|}
\hline Omset per Bulan & Frekuensi & Persentase \\
\hline$<\operatorname{Rp} 25.000 .000$ & 83 & 81.4 \\
\hline Rp 25.000.001 - Rp 208.000.000 & 19 & 18.6 \\
\hline Total & 102 & 100.0 \\
\hline
\end{tabular}


Financial Literacy and Inclusion in MSME Performance
Berdasarkan hasil pengumpulan data dengan menggunakan google form, 81.4 persen responden memiliki usaha Mikro, sedangkan sebesar 16.7 persen memiliki usaha kecil. Responden yang memiliki skala usaha menengah dalam penelitian ini hanya sebesar 2 persen.

Tabel 7. Skala Usaha

\begin{tabular}{|l|r|r|}
\hline \multicolumn{1}{|c|}{ Ukuran Usaha } & Frekuensi & Persentase \\
\hline Usaha Mikro & 83 & 81.4 \\
Usaha Kecil & 17 & 16.7 \\
Usaha Menengah & 2 & 2.0 \\
\hline Total & $\mathbf{1 0 2}$ & $\mathbf{1 0 0 . 0}$ \\
\hline
\end{tabular}

Tabel 8 menunjukkan bahwa persentase UMKM terbesar (45.1\%) memiliki usia bisnis dengan rentang waktu 1 sampai dengan 3 tahun. Usia UMKM dengan rentang waktu lebih dari 5 tahun memiliki persentase terendah yaitu sebesar 9.8 persen, hal ini menunjukkan bahwa berdirinya UMKM di kota Bogor masih relatif baru. Adapun dari sisi kepemilikan UMKM dari 102 responden hanya 1 responden diposisi sebagai pengelola, sedangkan sisanya sebesar $99 \%$ responden adalah sebagai pemiliki UMKM tersebut (Tabel 9).

Tabel 8. Usia Bisnis

\begin{tabular}{|l|r|r|}
\hline \multicolumn{1}{|c|}{ Usia Bisnis } & Frekuensi & Persentase \\
\hline Start Up & 17 & 16.7 \\
1 - 3 Tahun & 46 & 45.1 \\
4 - 5 Tahun & 29 & 28.4 \\
> 5 Tahun & 10 & 9.8 \\
\hline Total & $\mathbf{1 0 2}$ & $\mathbf{1 0 0 . 0}$ \\
\hline
\end{tabular}

Tabel 9. Posisi Usaha

\begin{tabular}{|l|r|r|}
\hline \multicolumn{1}{|c|}{ Posisi Usaha } & Frekuensi & Persentase \\
\hline Owner / Pemilik & 101 & 99.0 \\
Pengelola / manajer & 1 & 1.0 \\
\hline Total & $\mathbf{1 0 2}$ & $\mathbf{1 0 0 . 0}$ \\
\hline
\end{tabular}

\section{Uji Kualitas Data}

\section{Uji Validitas}

Nilai uji validitas yang digunakan dalam penelitian ini adalah nilai Average Variance Extracted (AVE). Berdasarkan hasil uji validitas menunjukkan bahwa hasil uji validitas seluruh variabel dalam peneltian ini memiliki nilai AVE di atas 0.50 , sehingga dapat disimpulkan ketiga variabel yang ada telah memenuhi syarat valid.

\section{Uji Reliabilitas}

Hasil uji reliabilitas pada penelitin ini menunjukkan bahwa seluruh variabel telah memiliki nilai CA di atas 0.70 , sehingga dapat disimpulkan ketiga variabel yang ada dalam penelitin ini telah memenuhi syarat reliabel

Uji Asumsi Klasik

Uji Asumsi Regresi (Normalitas)

Hasil pengujian asumsi normalitas untuk model regresi penelitian ini dapat dilihat pada Gambar 3 berikut di bawah ini. Kesimpulan dari hasil pengujian asumsi tersebut bahwa model regresi yang dibuat telah memenuhi asumsi normalitas karena pola titik-titik pada masing-masing Q-Q Plot telah mengikuti garis diagonal. 


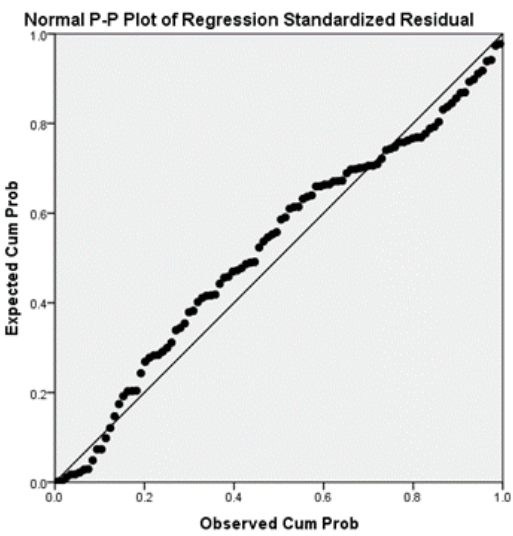

Financial Literacy and Inclusion in MSME Performance

\section{Gambar 7. Q-Q Plot Residual Model Regresi}

\section{Uji Asusmsi Regresi (Multikolinieritas)}

Hasil pengujian asumsi Multikolinearitas untuk model regresi penelitian ini dapat dilihat pada Tabel 11 di bawah. Kesimpulan dari hasil uji multikolinieritas menunjukkan bahwa model regresi penelitian ini tidak memiliki multikolinearitas karena seluruh nilai VIF variabel independennya bernilai lebih kecil dari 10.

\section{Tabel 12. Uji Multikolinieritas}

\begin{tabular}{|c|c|}
\hline Variabel & VIF \\
\hline $\mathrm{X} 1$ & 3.29 \\
$\mathrm{X} 2$ & 3.29 \\
\hline
\end{tabular}

\section{Uji Asumsi Regresi (Homoscedasticity)}

Hasil pengujian asumsi Homoscedasticity untuk model regresi penelitian ini dapat dilihat pada Gambar 4 berikut dibawah ini. Hasil pengujian dari asumsi tersebut menunjukkan bahwa model regresi penelitian ini telah memenuhi asumsi Homoscedasticity karena pola titik-titik pada masing-masing residual tidak membentuk pola tertentu.

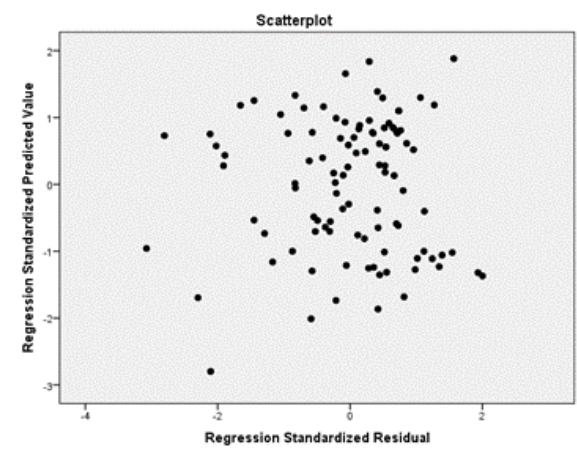

\section{Gambar 8. Plot Residual vs Prediksi}

\section{Uji Asumsi Regresi (Linearitas)}

Berdasarkan hasil sebelumnya dapat diketahui bahwa model regresi penelitian ini telah memenuhi asumsi normalitas dan asumsi homoscedasticity sehingga dapat disimpulkan bahwa model ini juga telah memenuhi asumsi linearitas. Adapun Persamaan regresi dalam penelitian ini: 
Financial Literacy and Inclusion in MSME Performance

\section{4}

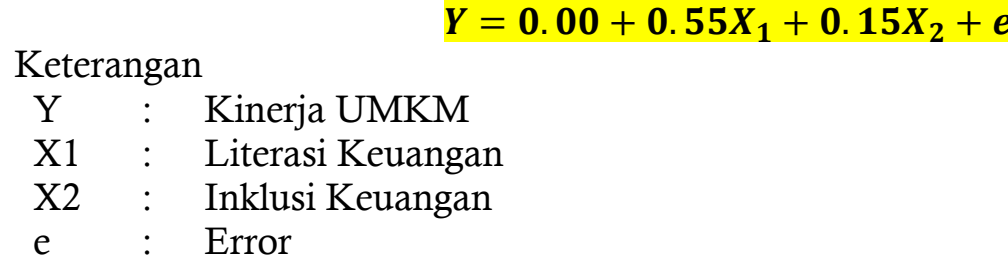

\section{Uji T (Uji Parsial)}

Pengujian T pada analisis regresi dilakukan untuk menguji apakah terdapat pengaruh dari masing-masing variabel independen yaitu literasi keuangan dan inklusi keuangan terhadap variabel dependen (kinerja UMKM). Suatu variabel independen dikatakan memiliki pengaruh terhadap variabel dependen jika nilai $p$-value ( $p$-hitung) hasil pengujiannya bernilai di bawah $0.05(\alpha=5 \%)$.

Tabel 13. Uji T

\begin{tabular}{|c|r|r|r|c|}
\hline \multicolumn{1}{|c|}{ Variabel } & $\begin{array}{c}\text { Koefisien } \\
\text { Regresi }\end{array}$ & T-hitung & P-Value & \multicolumn{1}{c|}{ Kesimpulan } \\
\hline Literasi Keuangan (X1) & 0.55 & 4.16 & 0.00 & Ada pengaruh \\
Inklusi Keuangan (X2) & 0.15 & 1.16 & 0.25 & Tidak ada pengaruh \\
\hline
\end{tabular}

Berdasarkan Tabel 13 di atas dapat diketahui bahwa hanya satu variabel independen saja yang memiliki nilai p-value (p-hitung) di bawah 0.05, yaitu Literasi Keuangan (X1), sehingga dapat disimpulkan untuk model regresi yang dibuat hanya variabel Literasi Keuangan saja yang memiliki pengaruh terhadap Kinerja UMKM.

\section{Uji F (Simultan)}

Uji F pada analisis regresi pada penelitian ini dilakukan untuk menguji variabel literasi keuangan dan inklusi keuangan secara bersama-sama apakah mampu memberikan pengaruh terhadap variabel kinerja UMKM. Variabel-variabel independen secara bersama-sama dikatakan memiliki pengaruh terhadap variabel dependen jika nilai $p$-value (p-hitung) hasil pengujiannya bernilai di bawah $0.05(\alpha=5 \%)$.

\section{Tabel 14 Uji F}

\begin{tabular}{|l|l|l|l|l|l|}
\hline & \multicolumn{1}{|c|}{$\begin{array}{c}\text { Sum of } \\
\text { Squares }\end{array}$} & $\begin{array}{l}\text { Degrees of } \\
\text { Freedom }\end{array}$ & $\begin{array}{c}\text { Mean } \\
\text { Square }\end{array}$ & \multicolumn{1}{|c|}{ F } & \multicolumn{1}{|c|}{ P-value } \\
\hline Regression & 48.06 & 2 & 24.03 & 44.11 & 0.00 \\
Residual & 53.94 & 99 & 0.54 & & \\
Total & 102.00 & 101 & & & \\
\hline
\end{tabular}

Berdasarkan Tabel 14 di atas dapat diketahui bahwa nilai p-value (p-hitung) dari hasil pengujian $\mathrm{F}$ adalah bernilai 0.00 , yaitu di bawah 0.05 , sehingga dapat disimpulkan bahwa variabel Literasi Keuangan dan Inklusi Keuangan secara bersama-sama memiliki pengaruh terhadap Kinerja UMKM.

\section{Analisis Koefisien Determinasi (R2)}

Hasil uji koefisien determinasi (R2) pada Tabel 15 di bawah ini menunjukkan bahwa nilai nilai R2 variabel kinerja UMKM sebesar 0.47 artinya variabel kinerja UMKM sebesar $47 \%$ dipengaruhi oleh variabel literasi keuangan dan inklusi keuangan sedangkan sisanya 53\% diperngaruhi oeh variabel lain di luar dari model penelitian ini. 
Tabel 15 Koefisien Determinasi (R2)

\begin{tabular}{|c|c|}
\hline R Square & Adjusted R Square \\
\hline 0.47 & 0.46 \\
\hline
\end{tabular}

Financial Literacy and

Inclusion in MSME

Performance

Di dalam penelitian ini terdapat tiga hipotesis diuji, yaitu:

H1 : $\quad$ Literasi Keuangan memiliki pengaruh terhadap Kinerja UMKM

H2 : Inklusi Keuangan memiliki pengaruh terhadap Kinerja UMKM

H3 : $\quad$ Literasi Keuangan dan Inklusi Keuangan secara bersama-sama memiliki pengaruh terhadap Kinerja UMKM

\section{Literasi Keuangan memiliki pengaruh terhadap Kinerja UMKM}

Berdasarkan hasil uji T yang dilakukan pada model regresi bagi variabel X1 (Literasi Keuangan), apabila hasil uji T untuk variabel X1 memiliki nilai $p$-hitung (p-value) di bawah 0.05 (atau 5\%), maka hipotesis ini dapat diterima. Berdasarkan pengujian t yang telah dilakukan sebelumnya dapat diketahui bahwa nilai $\mathrm{p}$-hitung dari uji $\mathrm{T}$ untuk variabel X1 adalah sebesar 0.00 , yaitu di bawah $5 \%$, sehingga dapat disimpulkan bahwa Literasi Keuangan memiliki pengaruh terhadap Kinerja UMKM.

\section{Inklusi Keuangan memiliki pengaruh terhadap Kinerja UMKM}

Berdasarkan hasil uji T yang dilakukan pada model regresi bagi variabel X2 (Inklusi Keuangan), jika hasil pengujian $\mathrm{T}$ untuk variabel X2 memiliki nilai $\mathrm{p}$-hitung ( $\mathrm{p}$-value) di bawah 0.05 (atau 5\%), maka hipotesis ini dapat diterima. Namun, berdasarkan uji t yang telah dilakukan sebelumnya dapat diketahui bahwa nilai p-hitung dari uji $\mathrm{T}$ untuk variabel X2 adalah sebesar 0.25 , yaitu di atas $5 \%$, sehingga dapat disimpulkan bahwa Inklusi Keuangan tidak memiliki pengaruh terhadap Kinerja UMKM.

\section{Literasi Keuangan dan Inklusi Keuangan secara bersama-sama memiliki pengaruh terhadap Kinerja UMKM}

Hipotesis ini dilakukan berdasarkan dari hasil uji $\mathrm{F}$ yang dilakukan pada model regresi. Apabila hasil uji $\mathrm{F}$ memiliki nilai p-hitung (p-value) di bawah 0.05 (atau 5\%), maka hipotesis ini dapat diterima. Berdasarkan uji $\mathrm{F}$ yang telah dilakukan sebelumnya dapat diketahui bahwa nilai p-hitung dari uji $\mathrm{F}$ untuk model regresi adalah sebesar 0.00 , yaitu di bawah 5\%, sehingga dapat disimpulkan bahwa Literasi Keuangan dan Inklusi Keuangan secara bersama-sama memiliki pengaruh terhadap Kinerja UMKM.

\section{PENUTUP}

Berdasarkan hasil analisis data dan pembahasan yang dilakukan pada penelitian ini maka simpulan untuk setiap hipotesis dapat dijelaskan sebagai berikut:

1. Literasi keuangan berpengaruh terhadapa kinerja UMKM

2. Inklusi keuangan tidak berpengaruh terhadap kinerja UMKM

3. Literasi keuangan dan inklusi keuangan secara bersama-sama berpengaruh terhadap kinerja UMKM

4. Hasil uji koefisien determinasi (R2) menunjukkan bahwa nilai nilai R2 variabel kinerja UMKM sebesar 0.47 artinya variabel kinerja UMKM sebesar $47 \%$ dipengaruhi oleh variabel literasi keuangan dan inklusi keuangan sedangkan sisanya 53\% diperngaruhi oleh variabel lain di luar dari model penelitian ini.

DAFTAR PUSTAKA

[1] ACCA (Association of Chartered Certified Accountants). 2012. Integrated Reporting: the Influence of King III on Social, Ethical and Environmental Reporting. 
Financial Literacy and Inclusion in MSME Performance

\section{6}

[2] Ahmad, fadil. 2017. UMKM Indonesia Masih Peringkat Ketiga di ASEAN. https://www.industry.co.id/read/2313/umkm-indonesia-masih-peringkat-ketigadi-asean. (6 Januari 2017)

[3] Anggraeni, Birawani Dwi. 2016. Pengaruh Tingkat Literasi Keuangan Pemilik Usaha Terhadap Pengelolaan Keuangan, Studi Kasus: UMKM Depol. Jurnal Vokasi Indonesia: Vol 4. No.1

[4] [anonim]. 2018. Ini Kontribusi Koperasi dan UMKM Terhadap PDB Nasional 2017. https://legaleraindonesia.com/ini-kontribusi-koperasi-dan-umkm-terhadappdb-nasional-2017/. (7 Januari 2018)

[5] Aribawa, dwitya. 2016. Pengauh Literasi Keuangan Terhadap Kinerja dan Keberlangsungan UMKM di Jawa Tengah. Jurnal Siasat Bisnis: Vol 20 No.1

[6] Ashariyadi. 2016. Menjadikan UMKM Berdaya Saing di Era MEA. Jakarta: Majalah Masyarakat ASEAN: Edisi 12.

[7] Baker, Emanuel R., Fisher, J Matthew and Goethert Wolfhart. 2007. Basic Principlesand Conceptsfor Achieving Quality. Software Engineering Institute. Carnegie Mellon University

[8] Baron, R. (2014) The Evolution of Corporate Reporting for Integrated Performance.Background paper for the 30th Round Table on Sustainable Development 25 June 2014. Paris : OECD Headquarters.

[9] Barth, Mary E. Including Estimates of the Future in Today's Financial Statements. Accounting Horizons: September 2006, Vol. 20, No. 3, pp. 271-285

[10] Beest, F. van, B. Braam, \& S. Boelens. (2009) Quality of Financial Reporting: Measuring Qualitative Characteristics. NiCE Working Paper. Nedherland: Radboud University Nijmegen

[11] Botosan, Christine A. 2004. Discussion of a framework for the analysis of firm risk communication. The International Journal of Accounting, 2004, vol. 39, issue 3, 289-295

[12] Carcello, J.V. Hollingsworth, C.W. klein, A. Neal, L.T. (2006). Audit Committee Financial Expertise, Competing Corporate Governance Mechanisms, and Earnings Management", February, available at www. ssrn.com.

[13] Chen, Haiyang dan Volpe, Ronald P. 1998. An analysis of personal financial literacy among college students. Financial Service Review: Volume 7

[14] Chepngetich, Prisca. 2016. Effect of Financial Literacy and Performance SMEs. Evidence from Kenya. American Based Research Journal: Vol. 5

[15] Cooper, J. \& Fisher, M., eds. 2002. Software Acquisition Capability Maturity Model (SA-CMM) Version 1.03 (CMU/SEI-2002-TR-010, ADA399794). Pittsburgh, PA: Software Engineering Institute, Carnegie Mellon University.

[16] Departemen Pengembangan UMKM Bank Indonesia. 2016. Pemetaan dan Strategi Peningkatan Daya Saing UMKM Dalam Menghadapi Masyarakat Ekonomi ASEAN (MEA) 2015 dan Pasca MEA 2025. Working paper: Jakarta

[17] IAASB. (2012) Feedback Statement the Evolving Nature of Financial Reporting: Disclosure and Its Audit Implications. New York: IAASB.

[18] IASB. (2008) Exposure Draft of An Improved Conceptual Framework for Fiancial Reporting. UK: IFRS Foundation

[19] International Accounting Standards Board. (2010). The Conceptual Framework for Financial Reporting 2010. London: IASB

[20] Ikatan Akuntansi Indonesia. 2012. Standar Akuntansi Keuangan. Jakarta: Salemba Empat.

[21] International Accounting and Reporting Issues : Review 2010. 2011. United Nation Confreence on Trade and Development. United Nation: New York \& Genewa

[22] KPMG. (2013) Audit Committee Institute-Global Audit Committee Survey, KPMG International Cooperative

[23] Sekaran, Uma \& Roger Bougie. (2013) Research Methods for Business: A Skill Building Approach. Sixth Edition. US:John Wiley \& Sons Ltd 